\title{
Adaptation to a changing environment: the response of marshland communities to the late medieval 'crisis'
}

\author{
Stephen Rippon
}

\begin{abstract}
Coastal marshlands form one of the many distinctive landscapes - or pays - within the British Isles. Their reclamation generally began during the early medieval period, and by the 12th and 13th centuries they were extensively settled and used for mixed agriculture, much like the adjacent dryland areas. It would be expected that the late medieval climatic deterioration, population decline and its associated socio-economic changes would have led to a marked decline in the settlement of such physically challenging areas but this was not generally the case. This paper examines how the communities living in coastal marshlands responded to the increase in flooding, declining population and falling profits from agriculture through a combination of increased investment and agricultural innovation, and that these cultural responses can only be understood by placing these specific landscapes within their wider context.
\end{abstract}

Key Words: Climatic deterioration; Marshland; Late medieval; Reclamation

\section{Introduction}

One of the major achievements of wetland archaeology has been its integration with other disciplines, notably palaeoecology and sedimentology, and a number of studies have extended this principle to the use of documentary material and its integration with information contained within the historic landscape (e.g. Hall 1996; Rippon 1996; 1997a; 2000a; Silvester 1988; Williamson 1997). This paper hopes to continue this tradition, and was first presented at the British Academy symposium on 'Wetland Landscapes and Cultural Responses' in February 2001. Its intention is to show the value of using historical sources in combination with physical (notably historic 
landscape) evidence when trying to understanding how human communities perceived and responded to the challenges that wetlands present - an essential prerequisite to understanding the archaeological record.

\section{The late medieval crisis in medieval England}

The later medieval period (the 14th and 15th centuries AD) saw profound changes in the English countryside as plague and famine caused population and prices to fall, and the practice of agriculture, along with the tenurial structures within which it occurred, adjusted to the new social and economic circumstances. This was also a period of climatic deterioration the significance of which, though probably overestimated for most of lowland Britain, had a profound impact upon the physically more difficult environments, such as low-lying coastal wetlands.

The decline in population that so characterises the 14th century appears to have started in the early part of that century, notably with the famines of 1315-17 (e.g. Poos 1985, 521; Titow 1961, 220). Though there was some recovery in subsequent decades (e.g. Razi 1980, 45), the Black Death killed c.30-45\% of the population, and along with its recurrent outbreaks throughout the later 14th century, there was demographic instability for well over a hundred years (Miller 1991b,3). Nationally, a population of 4.5-6.0 million in the early 14th century was reduced to $2.5-3.0 \mathrm{~m}$ in 1377, and perhaps as low as 2.0-2.5 million in the mid-15th century (Hatcher 1977, 68-70; Miller 1991b, 6). The long term implications were far reaching: falling population led to a decline in food prices, land prices and rents, giving rise to profound changes in the way that lords and their tenants exploited their estates. The profits that lords could achieve through directly managing their own demesne declined, leading to a marked trend towards the more conservative option of leasing - or 'farming' - out their lands. Initially, this occurred in a piecemeal fashion, though over time there was a trend towards leasing entire demesnes to one or more individuals. As the length of leases also increased, these 'farmers' could have an important part to play in shaping the landscape. Set against a general shift towards pastoralism, there was also increasing regional specialisation in agriculture, culminating with the large-scale conversion of arable to sheep pasture from the later 15th century (Beresford 1954, 83-93; CarusWilson and Coleman 1963; Hatcher 1970, 146-7; Miller 1991b, 10-11; Thirsk 1967, $213-$ 38).

\section{The late medieval contraction of settlement}

Many of these socio-economic trends impacted upon the historic landscape as it could no longer support as many agricultural units (tenements/farms). The traditional Malthusian view was that agriculture during the 13th century had become unsustainable, leading to a retreat from 'marginal' environments during the late medieval period (see Hoskins 1955, 120-1; Postan 1972, 31-9). In certain regions the farming of less profitable areas, which had only come to be cultivated during the 
preceding centuries of high population, climatic amelioration and economic prosperity, were indeed abandoned, and although the wholesale desertion of villages was in fact fairly uncommon at this period, the shrinkage of settlements, particularly on areas of poorer soil, was not uncommon (e.g. Britnell 1991, 56-7; Davenport 1906, 52, 78; Dyer 1982; Hatcher 1970, 132, 156-9, 161-4; Hilton 1947, 100; Lomas 1984, 310; Postan 1973, 214-48; Rippon 1997a, 198-200, 248-51).

It might be expected that areas as prone to environmental deterioration as coastal wetlands would have suffered most from settlement shrinkage and desertion. Certain marshland landscapes did see marked depopulation, either because of erosion (e.g. southern Holderness and north east Essex: see below) or particularly severe flooding (e.g. the Pevensey Levels: see below). However, in most other marshland landscapes the extent of settlement desertion appears to have been less than on the adjacent drylands (e.g. the Norfolk Marshland: Figure 1, and see Davison 1994; Silvester 1988, 160). The same is true in Lincolnshire (Start 1993) and the Somerset Levels (Rippon 1997a, 248-51). Why then did these apparently vulnerable coastal areas not suffer greater depopulation?

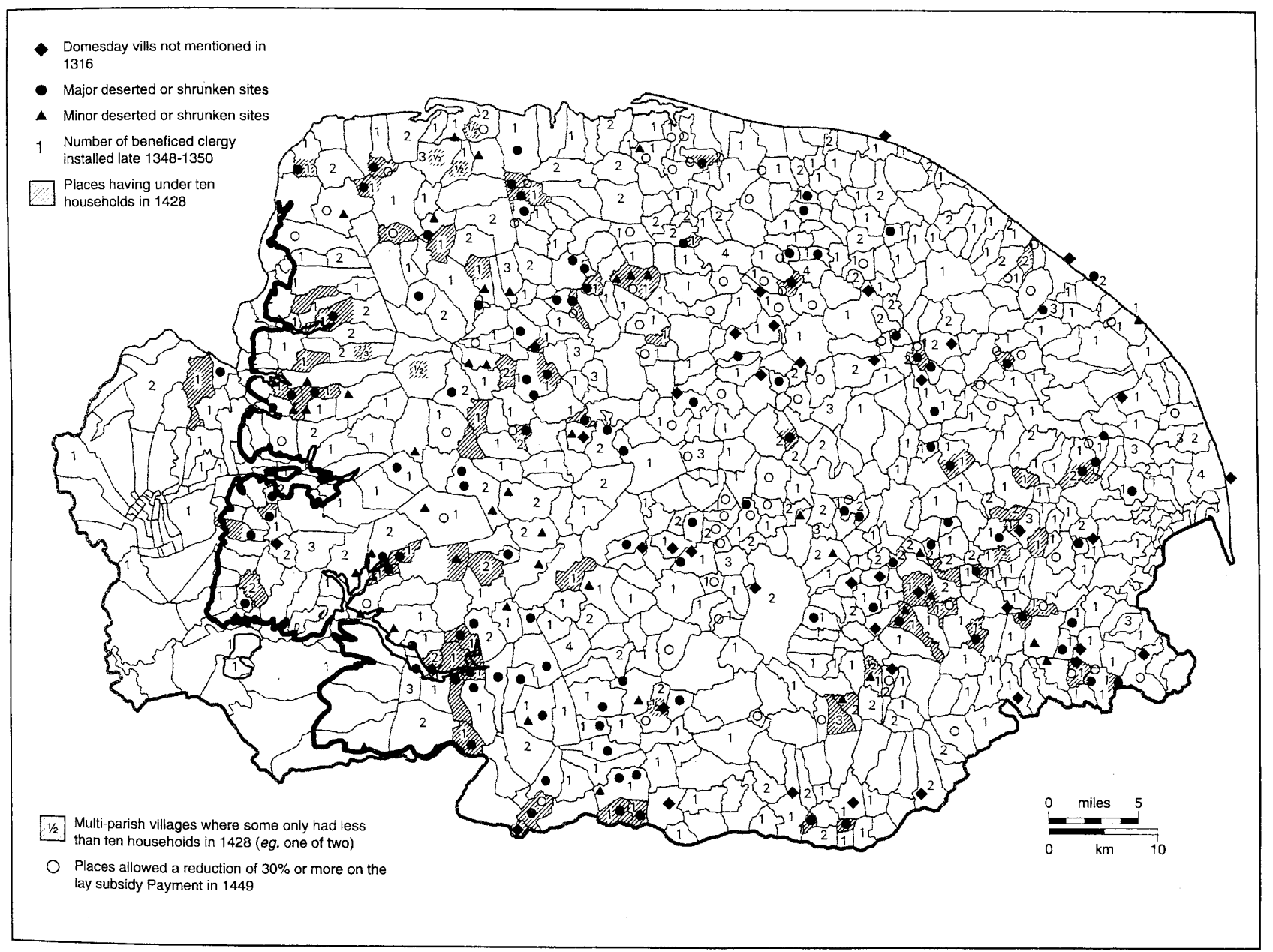

Fig. 1. Depopulation and settlement desertion in Norfolk. Source: Davison 1994, 85. 


\section{The late medieval crisis in coastal wetlands}

The concept of the 'margin' has been much debated, and while the physically deterministic views of earlier scholars such as Postan (1972) can be dismissed, it is undoubtedly true that certain landscapes are more amenable to certain types of agriculture than others due to physical factors, such as soil quality, and a wide range of cultural variables, such as proximity to centres of consumption and the structure of landholding (Bailey 1989; Dyer 1990; Gardiner 1998; Rippon 1997a, 2000a; Young and Simmonds 1995). As described above, late medieval society as a whole faced a series of general challenges, but whenever one studies a particular landscape it is important to consider how those general phenomena may have affected that specific area. Of the various problems experienced during the 14th and 15th century, three may be identified as being of particularly importance for communities living in coastal wetlands: declining population, climatic deterioration, and falling prices.

Life in coastal wetlands during the medieval period can be regarded as high cost, high risk and high return: high cost in terms of maintaining flooding defences, high risk in terms of the threat of flooding, but high return in terms of agricultural productivity (Rippon 2000a, 2-7). Conditions during the late medieval period, however, would certainly have made life more difficult. The costs of sustaining a reclaimed landscape would have increased as the lower population meant lower rent income and agricultural productivity, along with a smaller work-force to maintain the flood defences and deal with the increasingly frequent breaches in sea walls which resulted from the increased storminess.

The risks of living on coastal marshlands were also increasing during the late medieval period even though there is little evidence to suggest a rise in relative sea level (indeed, as temperature fell it appears that mean sea level actually fell: Jensen et al. 1993). Rather, the problem was an increased storminess (short-term weather events) that marked the onset of a longer-term climatic deterioration (Lamb 1995, 191-201). Occasional storm surges will always have caused flooding on coastal marshes, but conditions started to deteriorate appreciably around the mid 13th century with increased frequency of notably serious storms and floods (Bailey 1991; Bowler 1968, 31-4, 115; Grieve 1959, 8; Rippon 1997a, 242-5). Just as coastal landscapes were under increasing attack from the sea, another threat was from inland flooding. Precipitation that falls on the wetlands is not particularly significant; the problem is surface runoff from the adjacent uplands, and the huge catchments of the rivers that flow across coastal marshlands before they reach the sea. As a result, the increase in rainfall over late medieval Britain as a whole would have had a disproportionate impact upon coastal and other lowland wetlands.

With falling agricultural prices, leading to lower manorial income, the return on expenditure also fell. As the costs of maintenance increased, the risks of flooding increased, and the returns from agriculture fell, it might be expected that these landscapes would be amongst the first to be abandoned. That this was rarely the case, suggests that medieval society was well aware of the value and potential of these difficult environments, and it is the responses by human communities living in such areas to the increasingly difficult circumstances in which they found themselves, that will form the subject of this paper. 


\section{Coastal erosion: permanent land loss}

In a number of areas, the affects of the late medieval storms were disastrous, leading to extensive land loss due to erosion and flooding (Allen et al. 1994). In the Humber Estuary, for example, an area of reclaimed marshland perhaps 3-4 miles wide along with a number of settlements were lost on the southern side of Holderness (Sheppard 1966, 6-7). The shape of North East Essex is also a largely late medieval creation, with up to five miles of land being lost off Walton-on-the-Naze (Faith 1996; Morant 17638, 484; for erosion elsewhere around Essex see Andrews and Brooks 1989; Grieve 1959, 12; Morant 1763-8, 296; Nichols 1925; Spurrell 1885, 285). In Sussex, the marshes at Hastings where the Priory was located, were 'laid waste by the sea', and in 1407, John Pelham was granted lands in payment for demolishing the church (CPR 1405-7, 322; Ward 1920,113). To the east, at the mouth of the Combe valley, the settlement at Buverhythe also appears to have been abandoned due to coastal erosion (Burleigh 1973, 65; Holden 1962, 314).

\section{Extensive flooding: reversion to intertidal conditions}

Other areas, though not entirely lost to erosion, appear to have been so regularly flooded that they were virtually abandoned by the human communities that had once farmed them, and reverted to seasonally available grazing. In Sussex, for example, the Inquisitiones Nonarum suggests that the 1330s saw extensive flooding with areas ranging from 20 acres in Chidham though to 2,700 acres in Pagham being lost (Baker 1966; Blaauw 1848; Dulley 1966, 33). In total, 3,270 acres in Sussex are specified as having been submerged, although the lost tithe income in parishes where the actual area flooded is not specified, suggests that the actual acreage lost was closer to $c .5,500$ acres (c.2,226 ha; Blaauw 1848).

The Pevensey Levels provide a well-documented example. During the 1330s some 400 acres in Hooe, the greater part of an estate in Ninfield called 'Morhale', and 200 acres in Wartling which used to be cultivated were 'now submerged by the flood of water and sediment' (Blaauw 1848, 60). Flooding continued throughout the century, for example in 1371 when a crop of vetch was 'inundated during growth by an immense sea' (Brandon 1971b, 81-2). However, despite these problems, marshland arable remained highly valued and there was continued investment in agriculture (Brandon 1971a, 117; 1971b, 81; Searle 1974, 258, 454). Sea walls at Barnhorne were built or repaired in 1353/4,1374, 1375/6 and 1385/6, and during the 1380s investment in improved drainage for the 'brookland' permitted regular cropping for the first time for several decades. Around $40 \%$ of Barnhorne's arable at this time was on the marshlands, rising to $60 \%$ between 1396 and 1404 (Brandon 1971b, 82). The first decade of the 15th century, however, saw another period of serious flooding, and in 1408/9 all of Barnhorne's marshes were flooded, which led to a sudden transition from arable to pastoral farming. Once again, the manor's response was increased investment, with extra workmen hired to scour the sluices and water channels, repair the walls and replace the gates and bridges that had been washed away. However, 
conditions continued to deteriorate and in $1421 / 2$ there was the greatest flood ever to hit the Pevensey Levels, and subsequent years saw regular inundation (which can be identified in the sedimentological record: Moffat 1986, 85). Cattle farming came to dominate, and by the 1450s the eastern part of the Pevensey Levels appears to have been used for little more than seasonal grazing (Brandon 1971b, 83-4).

In Essex there were also extensive areas of saltmarsh in the 16th century, although there is evidence that some such areas had once been embanked. For example, on New England marsh (near Foulness Island) there is reference in 1598 to 35 acres of pasture within sea walls and 179 acres of saltmarsh which 'hath bene hertfore moste parte of it imbanked as appears by a mancion [mention] of an olde banke nowe decaised' (cited in Gramolt 1960, 127). In 1594 the topographical writer Norden described Canvey Island as a series of islands of 'low merishe grounds; and for that the passage over the creeks is unfitt for cattle, it is onlie conuerted to the feeding of ewes, which men milke, and therof make cheese (suche as it is), and of the curdes of the whey they make butter' (Norden 1594, 10). However, during the earlier 16th century there are occasional references to arable cultivation on the Island (Cracknell 1959, 16; Linder 1946, 49; Morant 1763-8, 266-7). The place-name 'Labworth alias Lubbins Farm', recorded as Lobwerde in 1260, also hints at earlier reclamation. The werda place-name appears to be related to the Dutch weerd/waard (= island or embanked area of marshland) and in Essex seems to relate to high medieval marshland reclamation (Reaney 1935, 148-9; Rippon 2000a, 207). During the 1430s there are references to embanking in that part of the Island belonging to Southchurch manor (Smith 1970,27), and in 1437 the Abbey of Christ Church Canterbury spent 38s 6d on repairing 154 perches $(774 \mathrm{~m}$ ) of embankment around its lands on Canvey (Priestley $1984,4)$. It would appear, therefore, that although Canvey was an extensive area of intertidal saltmarsh by the late 16 th century, this was a relatively recent state of affairs; another casualty of the late medieval crisis.

Such instances of whole marshlands being lost to either erosion or permanent flooding appear, however, to have been rare. Far more common was for concessions to be made by human communities that involved sacrificing certain areas in order to retain others, the process variously called 'set back', 'managed retreat' and 'managed realignment'

\section{The response to erosion: managed retreat along coastlines}

Along a number of coastlines, the present sea wall clearly cuts unconformably across the pattern of fields (Figure 2). This basic piece of landscape stratigraphy can be used to show that in a number of coastal wetlands, the present sea wall was not the original one behind which the present historic landscape was created. This has been shown most clearly off the Gwent Levels (Allen 1988; Fulford et al. 1994; Rippon 1996) where it appears that the original line of the sea wall lay several hundred metres out in the Severn Estuary (Allen and Rippon 1997). A close inspection of the field-boundary pattern suggests that the same phenomenon is seen in Fenland, though the lack of intertidal exposures prevents the extent of land loss to be assessed. In Cambridgeshire, 


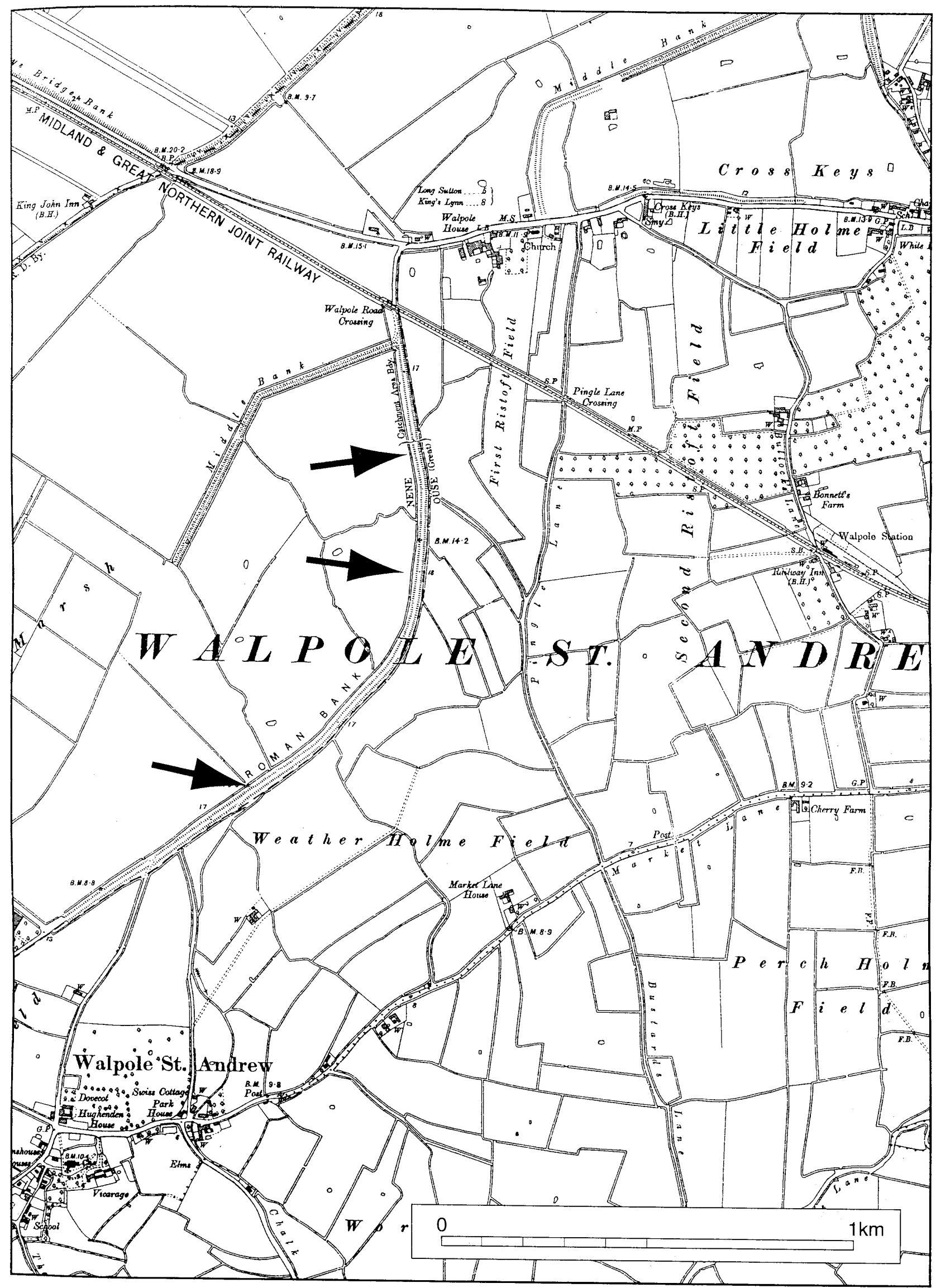

Fig. 2. Managed retreat in the Norfolk Marshland (Fenland). The sea wall in various places in Walpole St Andrew clearly cuts across the historic landscape, creating triangular shaped field-junctions (in the same way as the Midland and Great Northern Railway sits unconformably upon the landscape). Source: Ordnance Survey 1st Edition Six Inch Series. 
on the western side of the Wisbech inlet, the sea wall appears to have been set back across 'Newlondes' and 'Kakerow' in Newton (Hall 1981, fig. 4, appendix 1), while in Norfolk, the medieval sea wall is clearly set back in Walpole St Andrew and Terrington (Figure 2; Silvester 1988, 41). Another example of managed retreat can be seen on Romney Marsh. In 1302, for example, it was recorded that Winchelsea Marsh could not be saved, and a new wall 350 rods $(1.7 \mathrm{~km})$ in length was ordered to be built leaving 60 acres for formerly embanked land exposed outside (Homan 1938, 223).

\section{The response to erosion: managed retreat in the backfens}

Increased rainfall in the late medieval period would have had its greatest impact on the low-lying backfens of the major coastal wetlands, as increased runoff from the adjacent uplands was slow to discharge through the embanked and reclaimed coastal marshes. The survival of relict landscapes in a number of backfens suggest that some areas that had been enclosed and drained were abandoned sometime around the late medieval period, though precisely when is unclear (e.g. West Fen in Norfolk Marshland: Figure 3, Silvester 1988, 32-4; Banwell Moor on the North Somerset Levels: Rippon 1997b, 44-7; Huntspill Moor in the Central Somerset Levels: Rippon 1997a, 210-12). In the Lincolnshire Fens, limited documentary evidence may also suggest that some areas had reverted to fen (Miller 1951, 100).

Such examples of landscape abandonment are, however, rare and detailed work around Sedgemoor and the Brue Valley in the Central Somerset Levels produced no such evidence for relict landscapes (Musgrove 1999). In a number of places, what had been described as meadows or arable had reverted to pasture or even waste (notably around Meare) but overall, the documentary evidence suggests that whilst expansion into the backfen had ceased, what had been enclosed and drained was maintained (Musgrove 1999, 104-5, 113, 127-31, 146-8). There may even have been some further enclosure and drainage in a handful of places (e.g. Smallmoor in Walton: Musgrove 1999, 127-8).

\section{Romney Marsh: maintenance of a landscape and continued investment}

Despite examples of managed retreat from both coastal areas and the inland backfens, the overall impression is that wetland communities worked hard during the late medieval period to maintain the landscapes into which so much effort had been invested. Romney Marsh provides a particularly well-documented example (Figure 4; Rippon 2000a, 157-67,190-99). During the late 13th century the western part of Romney Marsh, known as Walland Marsh, was devastated by floods as the town of (Old) Winchelsea, and the shingle barrier upon which it stood, was washed away (Eddison 1998; Gardiner 1988). Rather than forcing the abandonment of this area, however, these floods initiated a remarkable period of investment. In 1292/3, for example, Christ Church Priory rebuilt three perches of wall in Nova Terra (Newland), and in 1298/9 two furlongs and 22 perches of new wall were built at Agney contra mare 


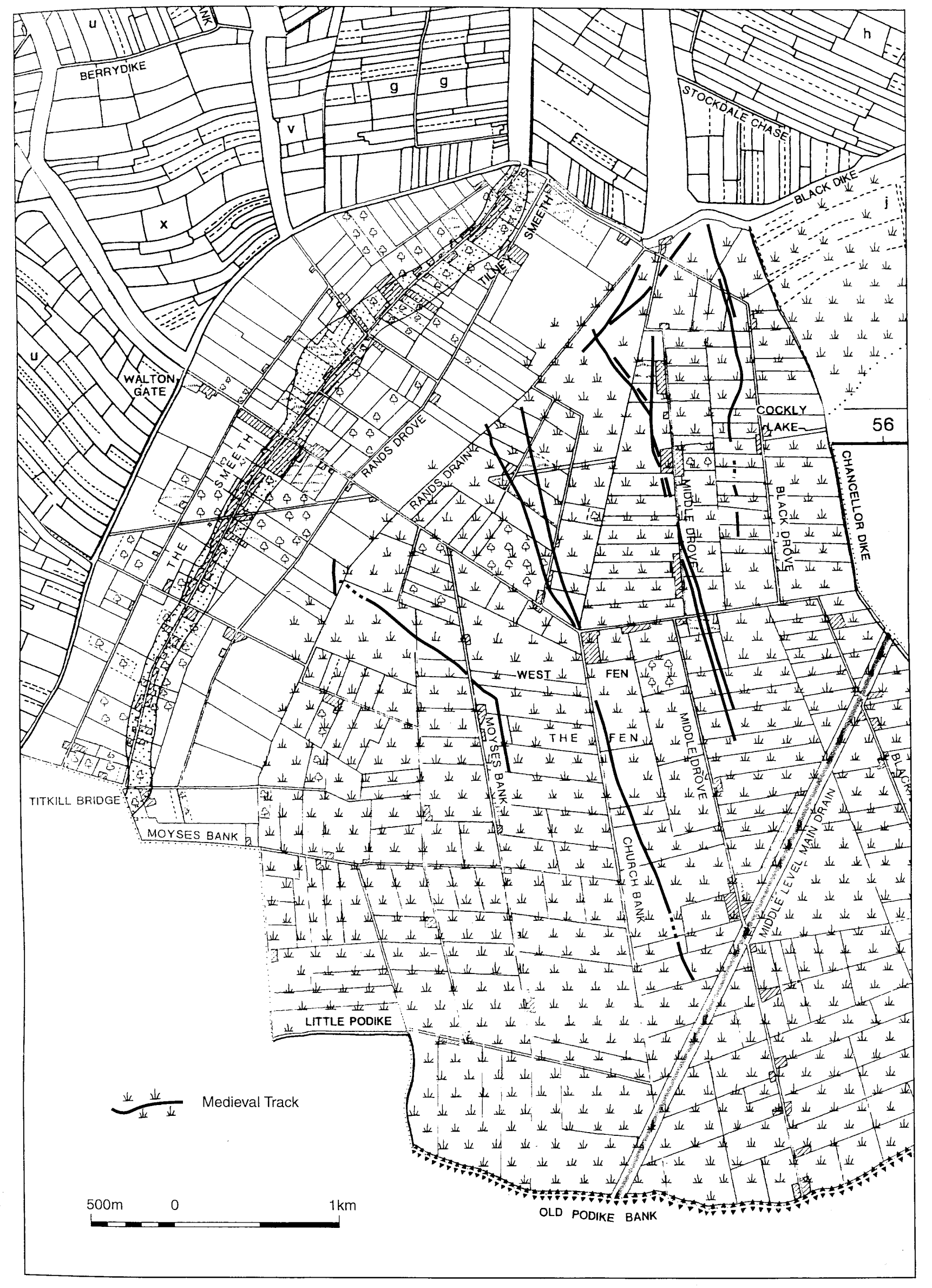

Fig. 3. Relict landscape in West Fen (the low-lying backfen of Norfolk Marshland, Fenland). Various of the earthworks appear to continue the line of elements in the historic landscape (such as the droves) and so presumably date to the same period (ie the 13th century). Source: Silvester 1988, fig. 124. 


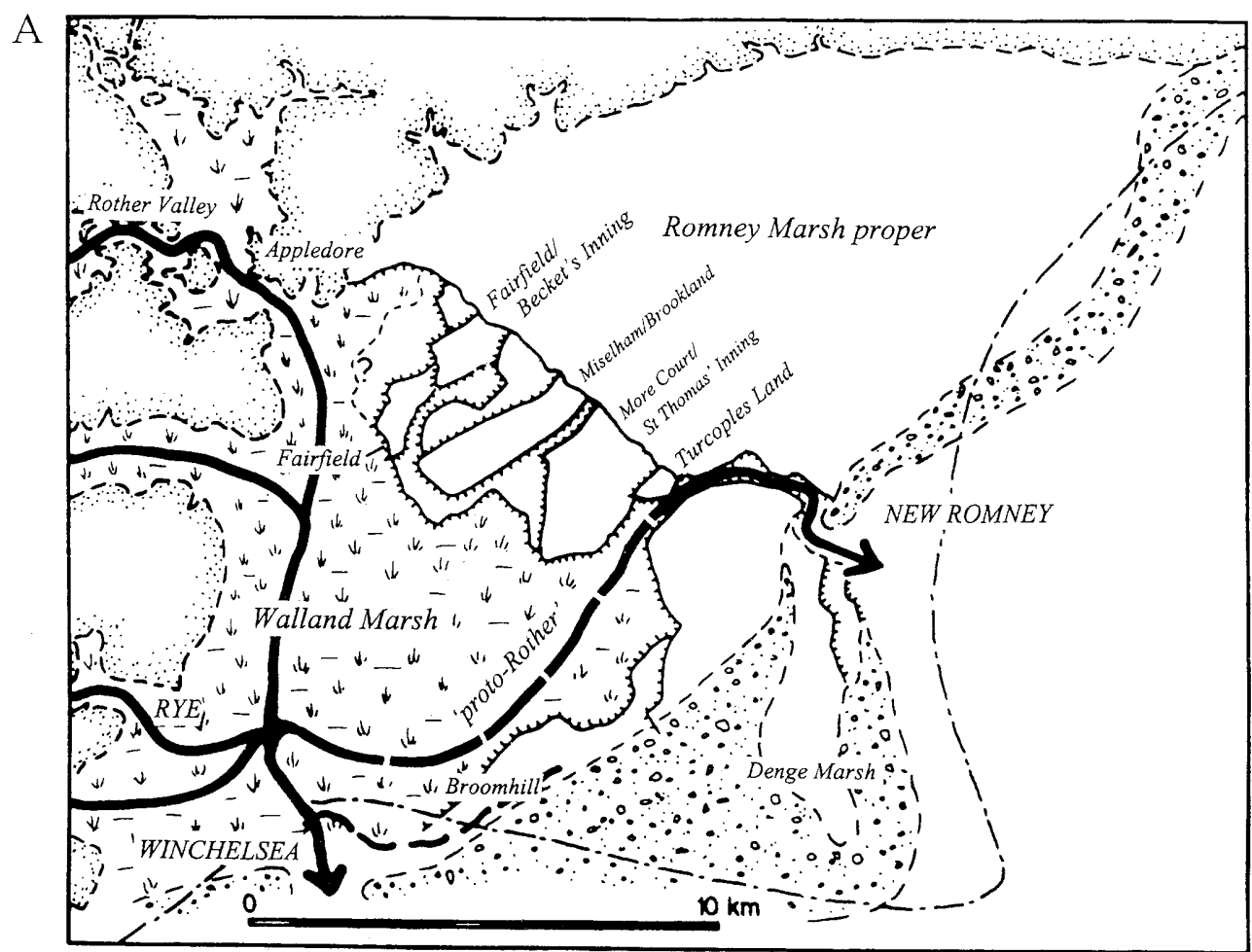

B

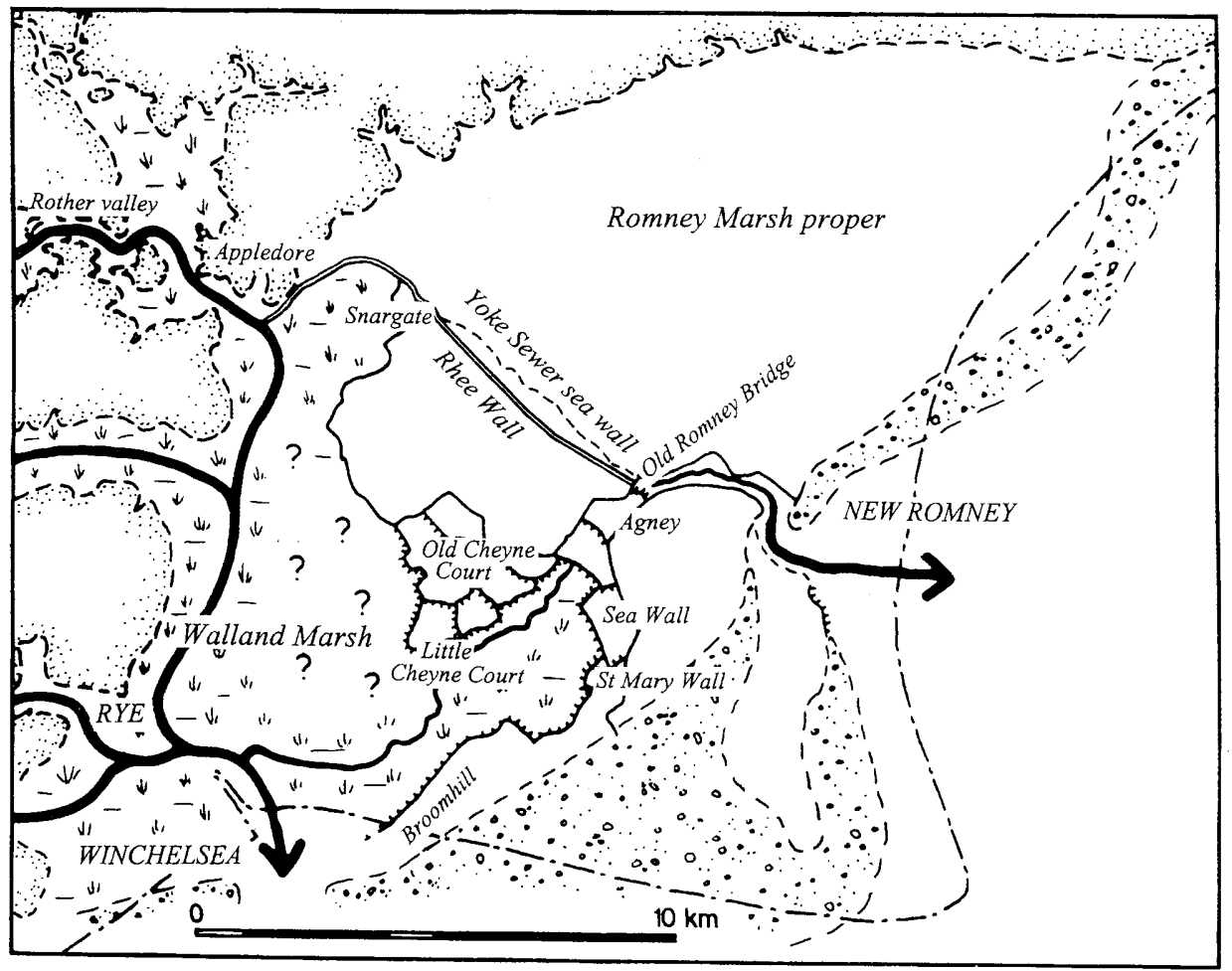

Fig. 4. The development of the landscape on Romney Marsh. 'Romney Marsh proper' was reclaimed during the early medieval period. A: During the 12th century a series of innings then started to embank Walland Marsh. B: 13th century inning in the vicinity of Agney and Old Cheyne Court following the diversion of the 'proto-Rother' river from New Romney to a new outfall at Winchelsea. The extent of reclamation in Walland Marsh is unclear because of later flooding. 
C

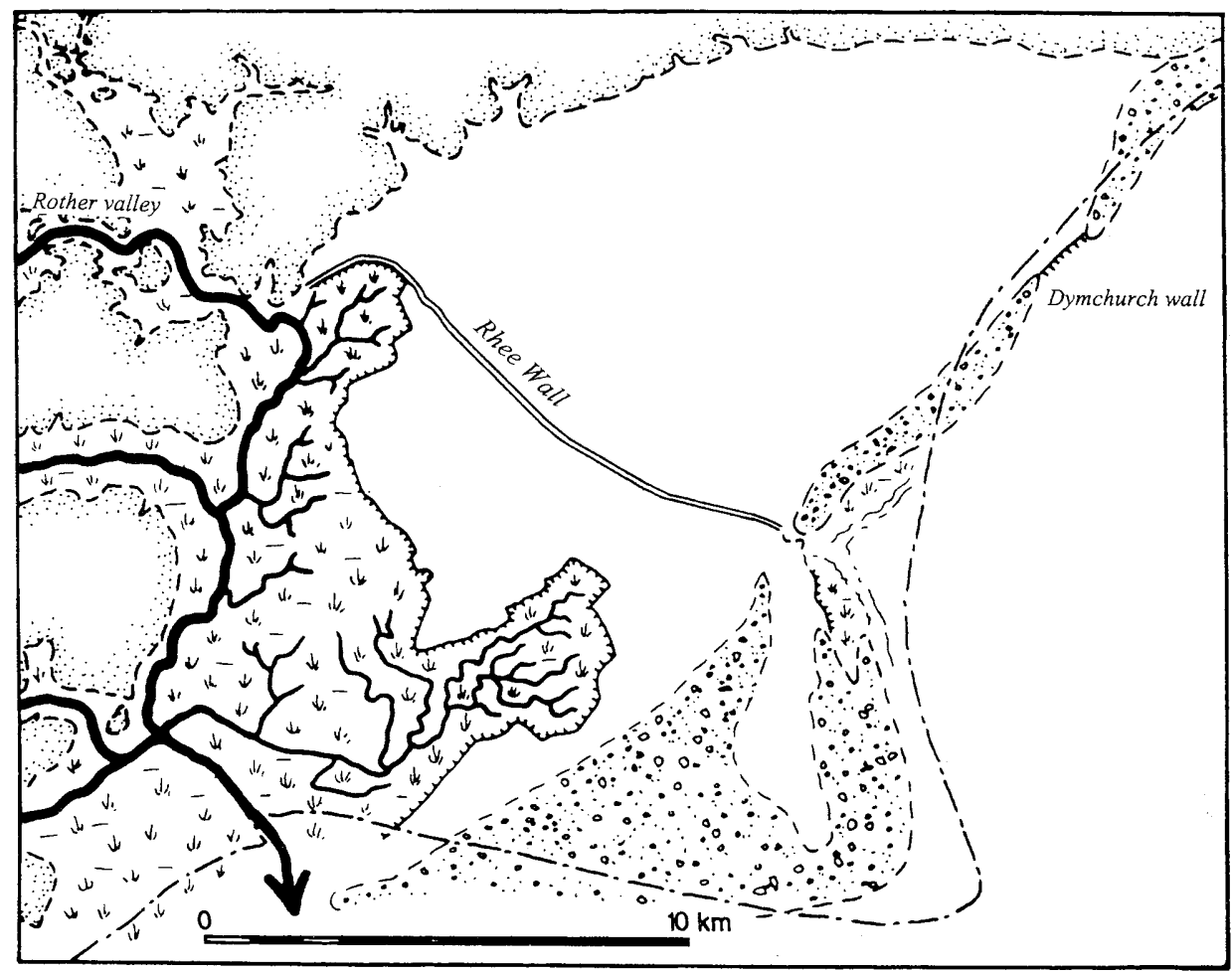

D

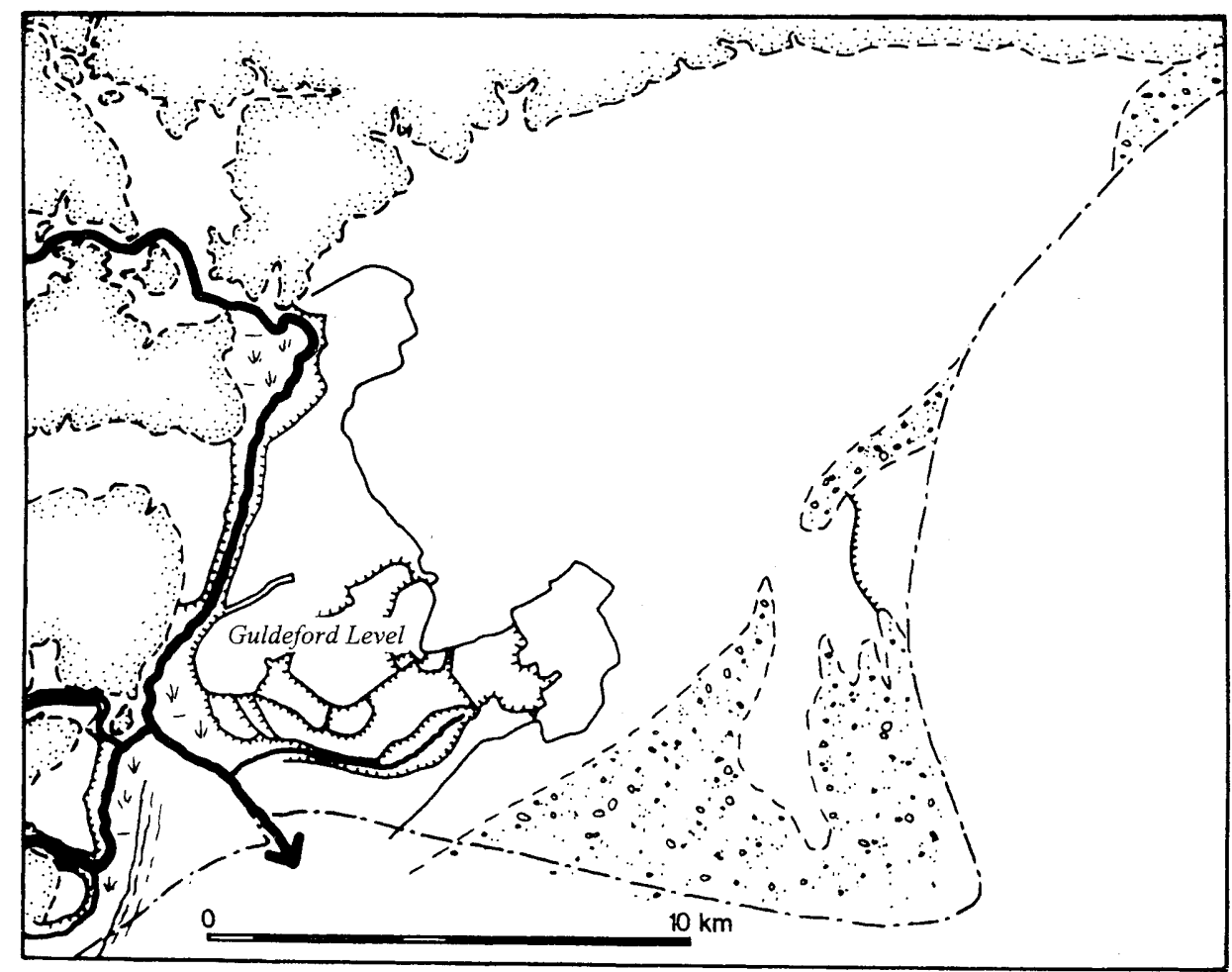

Fig. 4. (continued) C: late 13 th/14th century flooding. D: later 14 th and 15 th century recovery in Walland Marsh and the Guldeford Level. Source: Rippon 2000a, fig. 67. 
(against the sea) (Gross and Butcher 1995; Tatton-Brown 1988, 108-10; Smith 1940; 1943). Two dams were added in $1310 / 2$ to regulate the flow of water in the sewers, and by $1315 / 16$ the nova terra was cultivated land, having five and a half acres sown with oats and four with vetch (Smith 1943, 183).

Other great monastic landlords were similarly proactive. In 1309, the Abbey of Robertsbridge was granted a licence to purchase land and rents 'in consideration of the great loss sustained by that house through the sea having inundated the marshes of Winchelsea, Rye and Broomhill by the sea-coast' (CPR 1307-13, 152). Canterbury Cathedral Priory invested considerable sums on its estates at Appledore, Ebony and Agney (Smith 1940; 1943; Gross and Butcher 1995), and one example was the major area of pasture at Ebony known as Prioratus. This was surrounded by an embankment, the vetus walla, of which 80 perches were strengthened in $1286 / 7$. During the following year, an adjacent 28 acres were inned at a cost of $£ 310$ s, and a new embankment, the nova walla, was erected at a cost of $£ 8$ 7s. In 1293-4 a bill of $£ 12814 \mathrm{~s} 9 \mathrm{~d}$ was incurred for embanking work in Appledore, even though total manorial income was only $£ 74$ 3s (Gross and Butcher 1995, 108; Smith 1940, 3, 30; 1943, 173-4).

Overall, a huge amount appears to have been spent restoring flood defences and improving the land. The late 13th century was a time of high population and high grain prices making the direct management of demesne highly profitable, though when the climatic deterioration continued into the 14th and 15th century landlords continued to invest in their estates. Serious flooding returned to Walland Marsh in the mid 14th century, and in 1351, for example, it is recorded that 'the marsh of Spadelond lying between the Town of Winchelsea and Daunsewalle, and between Pykam Myll [near the top of the Pannel Valley] and Trecherie [below the Strand Gate of Winchelsea] is utterly torn and destroyed by storm of the sea so that the lands of the King and others are inundated at every high tide' (cited in Homan 1938, 223). The extent of this 14th century flooding can be seen through combining evidence for the complex pattern of sea walls in Walland Marsh and the detailed plotting of medium textured calcified soils (Rippon 2000a, figs 55 and 67).

Initially the major landowners once again set about recovering their flooded lands. In 1399, for example, a survey was carried out that recorded ' 628 acres of marsh, lying in a place called the Becard, which had long been in danger of the sea, and at times were often overflowed, ought to be preserved and defended by a certain bank beginning at Fayrefields Hole [a breach of the old sea wall at Fairfield] extending to the bank of the Prior and Convent of Christchurch to the north' (Holloway 1849, 125). Prior Goldstone (1449-68) spent $£ 1,200$ on this work, a figure far above that spent in Ebony around 1300 (see above). Prior Petham (1471-72) spent a further $£ 300$ on the reclamation of a 300 acre marsh, and by the dissolution, Appledore Marsh was completely inned and rendered fit for grazing sheep and cattle. The value to landlords of these new enclosures is clearly shown in the level of rent income they obtained from leasing their lands, a practice which became particularly prevalent from the mid 15th century (Draper 1998).

Whilst some landlords continued to manage their own lands, others adopted a different solution as they started to lease their estates, shifting the responsibility for flood defence - and the opportunity to make a profit through renting the land - to the 
emerging class of 'yeoman' farmers. In 1359, for example, the Archbishop of Canterbury granted John de Gosebourn of Appledore ' 72 acres of land in his marsh lying outside the walls of his innings of La Cheyn called Eastwall between the land of the Abbot of Boxley on the south and land called Newlonde on the north' so that it might be embanked, creating the entirely new manor of New Cheyne (Tatton-Brown $1988,110,261)$. The greatest reclamation occurred in an area later to be called East Guldeford. In 1478 the Abbot of Robertsbridge granted Richard Guldeford 1,300 acres of saltmarsh in the parishes of Playden, Iden and Broomhill in Sussex. In 1497, Guldeford acquired further land, and in 1499 he was given permission to build a church in 'Guylforde Innynge, formerly Brunchings, which had been submerged for 300 years and lately recovered by him at great expense'. By his death in 1506 this area had become the parish of 'New Guldford', with 6 messuages, a church, and a mill (Salzman 1937, 151).

These various late medieval reclamations on Walland Marsh can still be identified in today's 'historic landscape', as they possess a distinctive morphology (Figure 5). The old reclamations, dating up to the later 13th century and still protected by the sequence of sea walls that were constructed up to that date, are characterised by a complex pattern of small fields. This arrangement reflects both the process of reclamation (often carried out piecemeal by individual tenants), the use to which the fields were put (high medieval agriculture on the Marsh including a considerable amount of arable cultivation), and the way in which the landscape was managed (with strong communal regulation and a long tradition of tenant's parcels being widely scattered). The late medieval reclamations, in contrast, were characterised by far larger fields which also reflect the process of reclamation (more systematic), the use to which the land was put (pasture) and the pattern of landholding (larger, more unified tenancies) (Draper 1998, fig. 7.3; Eddison 2000, 88-9; Gardiner 1998).

\section{Adapting to circumstances: economic re-orientation}

It has been shown that during the 14th and 15th centuries, communities living on reclaimed coastal marshland were under enormous pressure from the deteriorating late medieval climate but that, in most cases, the response of these communities, and their landlords, was not to abandon these lands but to invest heavily in their continued survival. This strategy can be thought of in terms of balancing the perceived cost of maintaining a reclaimed landscape, the risks of continued flooding, and the benefits of continued occupancy: clearly, based upon contemporary understanding of the situation, the benefits were thought to outweigh the costs and risks.

Those areas that were not totally lost to flooding largely continued in agricultural production, though there was a shift towards pastoralism. This was a general phenomenon in the late medieval period, as grain prices fell and wool prices rose, but coastal marshlands were particularly suited to pastoral farming with their high grass yields and rich meadows. Another factor, which has not received the attention that it deserves, is the extent to which leguminous crops were also grown (Tables 1 and 2). Beans were certainly cultivated in early medieval England, having been recovered 
from 'Middle Saxon' settlements in Fenland (Crowson et al. 2000, 216-7, 220, 223; Murphy 1993, 76; 1995, 29; and see Hooke 1985, 126), and their use in an area south east of a line from Dorset to the Wash was widespread by the later 13th century (Campbell 1988, 200-201; Rippon forthcoming; and see Currie 1988). Overton and Campbell (1999, tab. 7.4) estimate that in $13004.9 \%$ of arable was sown with legumes, which rose to $8.7 \%$ by 1380 and $10.2 \%$ in 1600 . Though most of the data we have relates to demesne farming, it would appear that the cultivation of legumes was also becoming increasingly widespread in certain areas amongst the tenantry, as gauged for example, through tithe payments (e.g. the estates of Leicester Abbey: Hilton 1947,

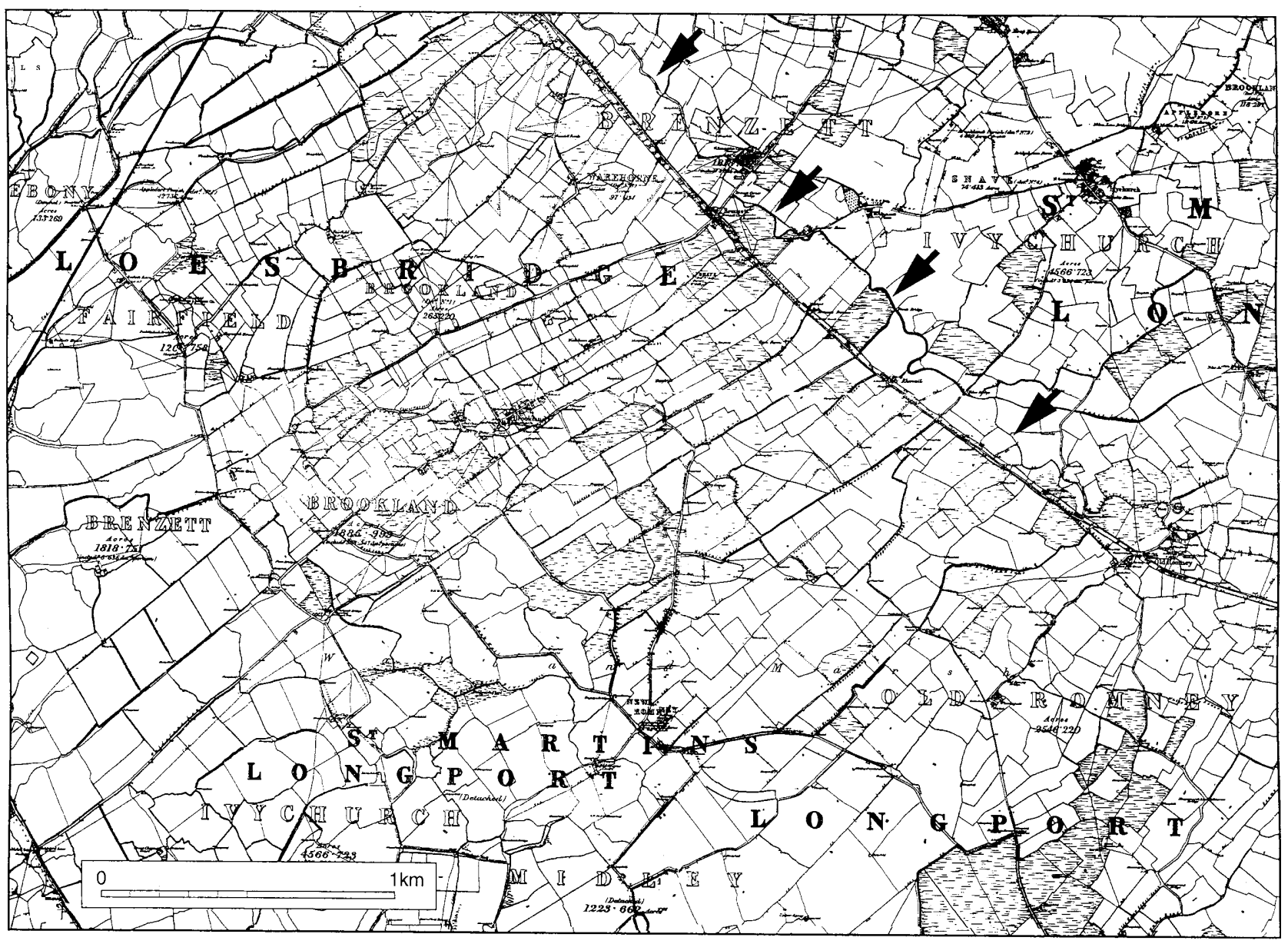

Fig. 5. The impact of landholding and landuse on the historic landscape of Romney Marsh. The older reclamations around Brookland are characterised by a complex pattern of small fields reflecting the process of reclamation (by individual tenants), landuse (including a considerable amount of arable cultivation), and the way in which the landscape was managed (with strong communal regulation and a long tradition of tenant's parcels being widely scattered). The late medieval reclamation to the south west (in a detached parcel of Brenzett parish), were characterised by far larger fields which also reflect the process of reclamation (more systematic), the use to which the land was put (pasture) and the pattern of landholding (larger, more unified tenancies). Source: Ordnance Survey First Edition Six Inch Series. 
65-6). Set against this generally upward trend, however, there was significant spatial and temporal variation with some areas showing a fall in the proportion of arable put down to legumes in the 15th century (e.g. Wisbech Barton: Stone 1998, app. 1; the Sussex manors of Battle Abbey: Brandon 1971a, tab. 1).

Similar quantified data is not available for many other areas in the late medieval period, though anecdotal evidence does point to the widespread cultivation of legumes on reclaimed coastal marshland. For example, of all the manors of St Augustine's Abbey (Bristol), Portbury, which included extensive areas of reclaimed marshland beside the River Avon, appears to have specialised in the cultivation of beans (Sabin $1960,5)$. The account rolls of Glastonbury Abbey's manors in the Somerset Levels do not unfortunately extend into the late medieval period (see Harrison 1997; Keil 1964), though in the 16th century the topographical writer Leland said: 'From Combane to the Sterte most parte of the shore is hilly ground, and nere the shore is no store of wood: that that is ys al in hegge rowes of enclosures. There is great plenty of benes in this quarter and inward to the landes. And of these benes ther is yn a maner a staple at Bridgwater when corn is dere in the parties beyond the se' (Toulmin Smith 1907, 168).

In Fenland, beans were grown on manors such as Gedney in 1364/5 (Campbell 1988, 203) and Gayton le Marsh in 1482-3 (Owen 1996, No. 84), and production in the region as a whole was at a level for a surplus to have been exported to London (Rigby

\begin{tabular}{|c|c|c|c|c|}
\hline \multirow[t]{2}{*}{ County } & \multicolumn{2}{|c|}{ Later $13^{\text {th }} /$ early $14^{\text {th }}$ century } & \multicolumn{2}{|c|}{ Later $14^{\text {th }} / 15^{\text {th }}$ century } \\
\hline & No. manors & $\begin{array}{l}\% \text { arable sown } \\
\text { with legumes }\end{array}$ & No. manors & $\begin{array}{l}\% \text { arable sown } \\
\text { with legumes }\end{array}$ \\
\hline \multicolumn{5}{|l|}{ Somerset Levels } \\
\hline Brent & 1 & $45.4 \%$ & & \\
\hline Sowy & 1 & $32.6 \%$ & & \\
\hline Withy & 1 & $100 \%$ & & \\
\hline \multicolumn{5}{|l|}{ Pevensey Levels } \\
\hline Pevensey Castle demesne & 1 & $16.4 \%$ & & \\
\hline \multicolumn{5}{|l|}{ Romney Marsh } \\
\hline Agney and Ogarswick & 1 & $36.8 \%$ & & \\
\hline Dengemarsh & 1 & $37.5 \%$ & 1 & $31.5 \% * *$ \\
\hline Udimore & & & 1 & $6.5 \%$ \\
\hline Norfolk Broads & 1 & $33.0 \%$ & & \\
\hline \multicolumn{5}{|l|}{ East Kent } \\
\hline Lydden & 1 & $31.0 \%$ & & \\
\hline \multicolumn{5}{|l|}{ Fenland } \\
\hline Downham-in-the-Isle & 1 & $30.0 \%$ & 1 & $30.0 \%$ \\
\hline Wisbech Barton & 1 & $5.2 \%$ & 1 & c. $3 \%$ \\
\hline Gedney & 1 & $15 \%$ & & \\
\hline
\end{tabular}

** in some years legumes comprised more than half the total acreage sown: Gardiner 1998, 133

Sources: see Rippon forthcoming

Table 1. Percentage of arable sown with legumes on marshland manors during the high and late medieval periods. 
1993, 59-60; Thomson 1944, lxi, 1xiv-1xv). From the 13th century rents were sometimes paid in beans (e.g. Foster 1.920, Nos 128, 259), and they were amongst the most common crops recorded in cases of theft (McLane 1988, Nos 17, 46, 219, 222, 230, 247, 291, 897, and 908). By the 16 th century, $30.6 \%$ of cultivated land in the marshland districts of Lincolnshire were sown with legumes, compared to $28.6 \%$ in the fenlands, $16.4 \%$ on the wolds and heaths and $30.9 \%$ on the clay vales (Thirsk 1967, tab. 14).

A variety of evidence, therefore, points to a relatively high proportion of the arable on many coastal marshlands having been put down to legumes. In a number of areas where quantified data is available, legumes comprised around $30 \%$ of cultivated land, a figure matched only by a handful of dryland regions (Table 2), and well above Overton and Campbell's (1999, tab. 7.4) national average of $8.7 \%$. So what does the extent of bean cultivation on reclaimed coastal marshlands suggest? Liking heavy soils and being relatively salt-tolerant, they are an ideal crop for coastal wetlands (Bland 1971, 269). Being a member of the Leguminosae, they can add nitrogen into soil

\begin{tabular}{|c|c|c|c|c|}
\hline \multirow[t]{2}{*}{ County } & \multicolumn{2}{|c|}{ Later $13^{\text {th }} /$ early $14^{\text {th }}$ century } & \multicolumn{2}{|c|}{ Later $14^{\text {th }} / 15^{\text {th }}$ century } \\
\hline & No. manors & $\begin{array}{l}\% \text { arable sown } \\
\text { with legumes }\end{array}$ & No. manors & $\begin{array}{l}\% \text { arable sown } \\
\text { with legumes }\end{array}$ \\
\hline Durham & 4 & $1.50 \%$ & 3 & $38.20 \%$ \\
\hline Suffolk & - & - & 5 & $34.20 \%$ \\
\hline Huntingdonshire & - & - & 6 & $32.50 \%$ \\
\hline Leicestershire & - & - & 17 & $29.70 \%$ \\
\hline W. Midlands + & 33 & $0.90 \%$ & 2 & $29.00 \%$ \\
\hline Kent & 26 & $21.70 \%$ & 7 & $25.10 \%$ \\
\hline Northamptonshire & 10 & $8.30 \%$ & 8 & $17.30 \%$ \\
\hline Cambridgeshire & - & - & 12 & $14.10 \%$ \\
\hline Sussex & 9 & $22.70 \%$ & 11 & $13.40 \%$ \\
\hline Yorkshire & 5 & $0.80 \%$ & 2 & $13.40 \%$ \\
\hline Gloucestershire & - & - & 7 & $12.50 \%$ \\
\hline Norfolk & 2 & $16.80 \%$ & 8 & $10.10 \%$ \\
\hline Essex & 3 & $1.50 \%$ & 22 & $7.50 \%$ \\
\hline Wessex (bishop of Winchester) & & $0.97 \%$ & & $6.60 \%$ \\
\hline Devon & 14 & $2.20 \%$ & * & $0.70 \%$ \\
\hline Cornwall & 4 & $4.30 \%$ & $*$ & $0 \%$ \\
\hline Nottinghamshire & 1 & $20.80 \%$ & & \\
\hline Dorset & 5 & $5.10 \%$ & & \\
\hline Oxfordshire & 8 & $4.00 \%$ & & \\
\hline Lancashire & 3 & $2.40 \%$ & & \\
\hline Somerset & 18 & $2.00 \%$ & & \\
\hline Wiltshire & 19 & $1.80 \%$ & & \\
\hline Northumberland & 4 & $0.70 \%$ & & \\
\hline Cumberland & 2 & 0 & & \\
\hline
\end{tabular}

* Number of manors not specified

+ West Midlands: Herefordshire, Monmouthshire, Warwickshire and Worcestershire

Sources: see Rippon forthcoming

Table 2. Percentage of arable sown with legumes in various English counties during the high and late medieval periods, arranged in ascending order in late medieval period. 
(Bland 1971, 269; Bond et al. 1985, 211), and their introduction into medieval agriculture may have started as part of crop rotations in order to improve soil fertility (e.g. Brandon 1972, 418; Campbell 1988, fig. 1; 1991, 144-5; Currie 1988; Gross and Butcher 1995, 109; Mate 1991; 1997; Postan 1966, 583; Titow 1969, 41). Contemporary medieval writings certainly show that the potential for growing legumes for this purpose was recognised (Thornton 1991, 196), though only when sufficient acreages $(20-25 \%)$ of legumes were grown in suitable rotations does it suggest that improving fertility was the prime intention (Farmer 1977, 564).

Comparison with the rest of medieval England suggests that the c.30-40\% of sown acreages on many marshland demesnes represents a highly specialised form of agricultural production. Beans are a protein-rich source of food for both humans or animals that can easily be stored dry or turned into bread/cake (Dyer 1989, 58, 154; Grieg 1988, 112-13; Howell 1983, 164; Searle and Ross 1967, 17, 126, 131; Tusser 1557, 57; Wretts Smith 1931/32,171). In a number of medieval accounts, it is specifically mentioned that beans were fed to pigs (e.g. Battle Abbey, Sussex: Searle and Ross 1967, 44; Chalvington in Sussex: Mate 1991, 82; Forncett in Norfolk: Davenport 1906, 31; Milton in Essex: Nichols 1932, 122-3, 149). Glastonbury Abbey's bean-growing manors on the Somerset Levels, notably Brent and Sowy, certainly had large herds of pigs (Keil 1964, 79, 81, 125). Of all Glastonbury's manors, the three largest herds of cattle (both for breeding and dairy production) were also located on these beangrowing marshland manors (Keil 1964, tab. 19). The preferential growing of beans on certain manors may also have been associated with the raising of horses. Glastonbury Abbey's only stud farms in Somerset were located at Brent and Sowy (Keil 1964, 81), and a tradition of horse breeding may be evident in Domesday, for manors in the Brent Marsh had a relatively high number of horses, including unbroken mares (Round 1906, 423).

From the discussion above, it appears that reclaimed marshland was highly valued as agricultural land, but that although large areas are recorded as arable, when detailed data on cropping is available it appears that beans were a major crop. Medieval estate managers were clearly making careful choices as to how they could most effectively utilise these distinctive environments, and the perception of landlords such as Glastonbury Abbey was that the high, particular pastoral, productivity of their marshland estates justified the costs and risks of maintaining flood defences.

\section{The paradox of Romney Marsh: investment and depopulation}

This discussion started with the observation that most marshland landscapes appear to have suffered less depopulation than their adjacent dryland areas. It has also been shown above how Romney Marsh was one of those marshland landscapes that saw the investment of considerable resources during the medieval period in order to combat the effects of flooding. Indeed, there was a similar degree of investment in other aspects of the landscape, notably ecclesiastical building programmes at Lydd, Ivychurch, Newchurch and Snargate (Tatton-Brown 1989, 261).

In the light of all this investment, it is curious that the Marsh was becoming steadily 
depopulated. In 1462, it was stated that 'in the Marsh of Romney, in the County of Kent, which lies and is situate near the sea, where there is now not so great an abundance of people and inhabitants or labourers, as there used to be' (quoted in Furley 1874,301$)$. In the early 16 th century, it was said that 'Romney Marsh, where corn and cattle were plentiful, has fallen into decay. Many great farms and holdings are held by persons who neither reside on them ... nor breed cattle, but use them for grazing trusting to the Welsh cattle' (quoted Sheail 1968, 226). The economic decline of Romney Marsh is reflected in the Lay Subsidy Returns of 1524/5, when the Marsh paid an average of 26-29 shillings per square mile, while few areas in the rest of Kent averaged less than 50 (Sheail 1968, 224, 331; and see Pearson 1994, 144). Blackmanstone, Broomhill, Eastbridge, and Orgarswick churches were probably abandoned by 1500, and two of the three parish churches in New Romney were pulled down by the mid 16th century (Robertson 1880; Tatton-Brown 1989, 262). Snave had no communicants by 1557 whilst Hurst church was converted into a pig sty (Gardiner 1998, 132); Hope All Saints and Midley churches were abandoned by the late 16th/early 17th century (Figure 6; Bennell 1995, 99; Tatton-Brown 1989, 262). Limited fieldwalking has also demonstrated a major thinning out the mainly dispersed settlement pattern with 52 sites in the Newchurch area dating to $c .1250-1400 / 1450$, falling to just 15 with occupation from 1400/1450 to 1500/1550; only a handful of these sites continued to be occupied into the 16th or 17th centuries before they too were abandoned (Reeves 1995, 84-5; and see Gardiner 1994). Excavations at Lydd Quarry suggest a slightly earlier date for the contraction of settlement there, around the mid 14th century (Barber 1998, 101).

Beresford $(1971,20)$ found the depopulation of Romney Marsh 'mysterious', because

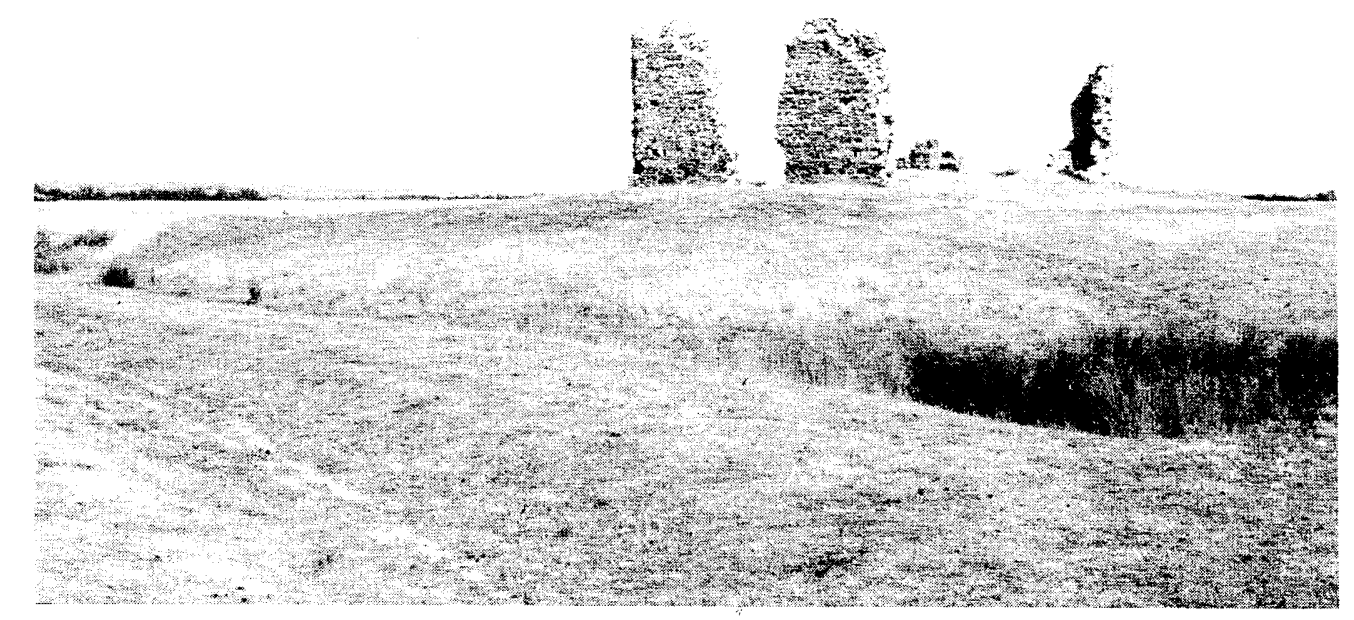

Fig. 6. Hope All Saints church, Romney Marsh (see Bennell 1995). The Marsh contains numerous isolated and even ruinous churches in what is now a sparsely populated area. 
of its scale: outside the region 'it is rare to find deserted villages with other deserted villages on every side of it'. A number of factors would appear to account for this economic decline, some of which were local in their effect. Like a number of areas, Romney Marsh suffered from recurrent bouts of plague, such as that which devastated the population of Hythe during the reign of Henry V (1413-22; Riley 1876b, 429-31; and see Dobson 1998). The Romney Marsh ports were suffering from the wars with France, and as trade became increasingly focused upon London and Southampton (Butcher 1974, 19; Lovegrove 1994, 5). At the same time both the Romney and Rother Estuaries were silting up despite strenuous efforts to keep them open (Eddison 1995b; Hipkin 1995, 138; Page 1937, 54; Riley 1874; 1876b; Vollans 1988). The loss of the local port towns meant that there was little local demand for labour, goods and services that might otherwise have allowed economic diversification (Gardiner 1998, 141).

Whilst local conditions on Romney Marsh were affecting its prosperity, the region was also responding to the general decline in demand for grain and increased demand for meat, dairy produce and particularly wool (see above). In a number of areas in Britain, economic diversification and the presence of towns, providing a market for goods and services, allowed communities to survive and even flourish (e.g. the Breckland of Suffolk: Bailey 1989). The rich pastures of the Marsh, in contrast, lay next to the established woolen industry of the Kentish Weald, and as sheep farming was much less labour intensive, a population decline was inevitable. Alongside this trend, there was also the policy of major ecclesiastical estate owners leasing their demesne (see above), allowing the peasantry to accumulate larger holdings, with butchergraziers, many of whom lived off the Marsh, being the most innovative of the new 'yeoman' farmers (Draper 1998; Dyer 1991; Gardiner 1998; Pearson 1995, 96-7).

Thus, decline in settlement on Romney Marsh can only be understood when this individual wetland is placed in its wider landscape context. The structure of land ownership and growing physical isolation meant that it was suddenly ill-placed to cope with the changing economic environment, in contrast to other marshlands such as Fenland and the Somerset Levels which lay within economically more vibrant regions with a flourishing urban network. The considerable investment by the great ecclesiastical landowners and their lessees in restoring drainage and flood defence appears to have been a commercial concern, which had little benefit to the local population.

\section{Conclusions}

This paper has examined just one type of wetland, coastal marshlands, during a very short period of time - the 14th and 15th centuries - and the human responses to a series of profound environmental and socio-economic changes: climatic deterioration, falling population and grain prices, and the changing relationships between lords and their tenants. The way in which any particular landscape evolves at any particular time can only be understood by placing it in its wider context, and these coastal marshlands provide a good example. All communities were affected by the general socio-economic phenomena of falling population which led to lower agricultural prices, 
though like the deteriorating climate this will have had a differential impact depending on regional factors such as the structure of landholding (e.g. the leasing of demesne), the willingness of landlords and tenants to adopt innovative agricultural practices (e.g. the cultivation of beans and specialisation on raising livestock), and proximity to centres of consumption (flourishing towns, ports and markets).

It has been shown that despite the socio-economic background of recession, and environmental conditions that made coastal wetlands increasingly difficult, life in what have traditionally been called 'marginal' landscapes had not become untenable. The cost and risks of the traditional pattern of mixed agriculture increased, and the returns decreased, but the overwhelming response was continued investment and innovation, not desertion. This must reflect the way in which society perceived the relative value of different strategies towards landscape exploitation, and suggests two possibilities: that late medieval society was highly conservative and had little idea of economic or environmental reality, or it suggests that coastal wetlands were highly valued by contemporary society and were regarded as worthy of continued investment. That other, far less challenging, landscapes suffered greater depopulation suggests that the latter is true, and that the cost, risks and returns of life in a wetland landscape were fully appreciated.

\section{Abbreviations}

CPR Calendar of Patent Rolls

\section{References}

Allen, J.R.L. 1988. Reclamation and sea defence in Romney parish, Monmouthshire. Archaeologia Cambrensis CXXXVII, 135-40.

Allen, J.R.L., Bradley, R.J., Fulford, M.G., Mithen, S.J., Rippon, S.J. and Tyson, H.J. 1994. The archaeological resource: a chronological overview, pp. 103-53 in Fulford, M., Champion, T. and Lomg, A. England's Coastal Heritage. London: English. Heritage.

Allen, J.R.L. and Rippon, S.J. 1997. Iron Age to Early Modern Activity and Palaeochannels at Magor Pill, Gwent: an exercise in lowland coastal zone geoarchaeology. Antiquaries Journal 77, 327-70.

Andrews, D. and Brooks, H. 1989. An Essex Dunwich: the lost church at Little Holland Hall. Essex Archaeology and History 20, 74-83.

Bailey, M. 1989. A Marginal Economy? East Anglian Breckland in the Later Middle Ages. Cambridge: Cambridge University Press.

Bailey, M. 1991. 'Per Impetum Maris': Natural disaster and economic decline in eastern England, 1275-1350, pp. 184-208 in Campbell, B.M.S. (ed.) Before the Black Death. Manchester: Manchester University Press.

Baker, A.R.H. 1966. Some evidence of a reduction in the acreage of cultivated lands in Sussex during the early fourteenth century. Sussex Archaeol. Coll. CIV, 1-5.

Barber, L. 1998. Medieval Rural Settlement and Economy at Lydd: Preliminary Results from the Excavations at Lydd Quarry. In Eddison, J. et al. (eds), 89-108.

Bennell, M. 1995. Hope All Saints: a survey and discussion of the ruins and earthworks. In Eddison, J. (ed.), 1995, 99-106.

Beresford, M.W. 1954. The Lost Villages of England. London: Lutterworth Press. 
Beresford, M,W. 1971. A Review of Historical Research (to 1968), in Beresford, M.W. and Hurst, J.G. (eds), 3-75.

Beresford, M.W. and Hurst, J.G. 1971. Deserted Medieval Village.s London: Lutterworth Press.

Blaauw, W.H. 1848. Remarks on the Nonae of 1340, as relating to Sussex, Sussex Archaeological Collections 1, 58-46.

Bland, B.F. 1971. Crop production: cereals and legumes, pp. 269-303 in Summerfield, R.J. and Roberts, E.H. (eds) Grain Legume Crops. Collins: London.

Bond, D.A., Lewis, D.A., G.C., Hawton, G.C., Saxena, M.C. and Stephens, J.H. 1985. Faba bean (Vicia faba L), pp. 199-265 in Summerfield, R.J. and Roberts, E.H. (eds) Grain Legume Crops. Collins: London.

Bowler, E.E.M. 1968. The Reclamation and Land Use of the Thames Marshes of North West Kent. Unpublished Ph.D. thesis, London School of Economics and Political Science.

Brandon, P.F. 1971a. Demesne arable farming in coastal Sussex during the later Middle Ages. Agric. Hist. Rev. 19(ii), 113-34.

Brandon, P.F. 1971b. Agriculture and the effects of floods and weather at Barnhorne, Sussex, during the later Middle Ages. Sussex Archaeol. Coll. 109, 69-93.

Brandon, P.F. 1972. Cereal yields on the Sussex estates of Battle Abbey during the later middle ages. Economic History Review, 2nd ser., XXV, 403-20.

Britnell, R.H. 1991. The Occupation of Land: Eastern England. In Miller, E. (ed.) 1991a, 53-67.

Burleigh, G.R. 1973. An introduction to deserted medieval villages in East Sussex. Sussex Archaeol. Coll. 111, 45-83.

Butcher, A.F. 1974. The Origins of Romney Freemen, 1433-1523. Economic History Review, 2nd series 27(i), 16-27.

Campbell, B.M.S. 1988. The diffusion of vetches in medieval England. Economic History Review, 2nd Ser. XLI, 193-208.

Campbell, B.M.S. 1991. Land, labour, livestock, and productivity trends in English seigniorial agriculture, 1208-1450, pp. 144-82 in Campbell, B.M.S. and Overton, M. (eds) Land, Labour and livestock: historical studies in European agricultural productivity. Manchester: Manchester University Press.

Carus-Wilson, E.M. and Coleman, O. 1963. England's Export Trade, 1275-1547. Oxford.

Coleman, M.C. 1984. Downham-in-the-Isle: a study of an ecclesiastical manor in the thirteenth and fourteenth centuries. Woodbridge: Boydell Press.

Cracknell, B.E. 1959. Canvey Island; the history of a marshland community. Leicester: Leicester University Press.

Crowson, A., Lane, T. and Reeve, J. 2000. Fenland Management Project Excavations 1991-1995. Lincolnshire Archaeology and Heritage Reports Series, No. 3.

Currie, C.R.J. 1988. Early vetches: a note. Economic History Review, 2nd Ser. XLI, 114-6.

Davenport, F.G. 1906. The Economic Development of a Norfolk Manor, 1086-1565. Cambridge: Camridge University Press.

Davison, A. 1994. Deserted villages and rural depopulation, pp. 84-5 in Wade-Martins, P. (ed.) An Historical Atlas of Norfolk. Norwich, Norfolk Museums Service.

Dobson, M. 1998. Death and Disease on Romney Marsh in the 17th to 19th centuries. In Eddison, J. et al. (eds) 1998, 196-82.

Draper, G. 1998. The Farmers of Canterbury Cathedral Priory and All Souls College on Romney Marsh c.1443-1545. In Eddison, J. et al. (eds), 109-128.

Dulley, A.J.F. 1966. The Level and Port of Pevensey in the Middle Ages. Sussex Archaeol. Coll. 104, 26-45.

Dyer, C. 1980. Lords and Peasants in a Changing Society: the estates of the Bishopric of Worcester, 6801540. Cambridge: Cambridge University Press.

Dyer, C.C. 1982. Deserted medieval villages of the west Midlands. Economic History Review, 2nd ser., XXXV, 19-34.

Dyer, C. 1989. Standards of Living in the Later Middle Ages, c.1200-1520. Cambridge: Cambridge University Press. 
Dyer, C.C. 1990. The past, present and future of rural history. Rural History 1(i), 37-50.

Dyer, C.C. 1991. 'Were there any capitalists in fifteenth-century England?', pp. 1-24 in Kermode, J. (ed.) Enterprise and Individuals. Gloucester.

Eddison, J. 1995b. Attempts to Clear the Rother Channel, 1613-1624. In Eddison, J. (ed.) 1995a, 14863.

Eddison, J. 1998. Catastrophic Changes: a multi-disciplinary study of the evolution of the barrier beaches of Rye Bay, in Eddison J. et al. (eds), 65-87.

Eddison, J. 2000. Romney Marsh: Survival on a Frontier. Stroud: Tempus.

Eddison, J., Gardiner, M. and Long, A. (eds) 1998. Romney Marsh: Environmental Change and Human Occupation in a Coastal Lowland. Oxford: Oxford University Committee for Archaeology Monograph 46.

Faith, R. 1996. The topography and social structure of a small soke in the middle ages: The Sokens, Essex. Essex Archaeology and History 27, 202-213.

Farmer, D.L. 1977. Grain yields on the Winchester manors in the later Middle Ages. Economic History Review 2nd ser. XXX(iv), 555-66.

Finberg, H.P.R. 1951. Tavistock Abbey: a study in the social and economic history of Devon. Cambridge: Cambridge University Press.

Foster, C.W. 1920. Final Concords of the County of Lincoln, AD 1242-1272. Lincolnshire Record Society 17.

Fulford, M.G., Allen, J.R.L., and Rippon, S.J. 1994. The Settlement and Drainage of the Wentlooge Level, Gwent: survey and excavation at Rumney Great Wharf 1992. Britannia 25, 175-211.

Furley, R. 1874. A History of the Weald of Kent. Ashford and London.

Gardiner, M. 1988. Medieval Settlement and Society in the Broomhill Area and Excavations at Broomhill Church, pp. 112-27 in Eddison, J. and Green, C. (eds) Romney Marsh: Evolution, Occupation, Reclamation. Oxford: Oxford Committee for Archaeology monograph 24.

Gardiner, M. 1994. Old Romney: an examination of the evidence for a lost Saxo-Norman port. Archaeologia Cantiana 114, 329-45.

Gardiner, M. 1998. Settlement Change on Denge and Walland Marshes, in Eddison, J. et al. (eds), $129-145$.

Gramolt, D.W. 1960. The Coastal Marshlands of East Essex between the seventeenth and mid-nineteenth centuries. Unpublished MA Dissertation, University of London.

Green, R.D. 1968. The Soils of Romney Marsh. Harpenden: Soil Survey of Great Britain.

Grieg, J. 1988. Plant Resources, pp. 149-87 in Astill, G. and Grant, A. (eds) The Countryside of Medieval England. Oxford: Blackwells.

Grieve, H. 1959. The Great Tide: the story of the 1953 flood disaster in Essex. Chelmsford: Essex Records Office.

Gross, A. and Butcher, A. 1995. Adaptation and investment in the age of the great storms: agricultural policy on the manors of the principle Lords of Romney Marshes and the marshland fringe c.1250-1320, in Eddison, J. (ed.), 107-17.

Hall, D. 1981. The Changing Landscape of the Cambridgeshire Silt Fen. Landscape History 3, 3749.

Hall, D. 1996. The Fenland Project, Number 10: Cambridgeshire Survey, Isle of Ely and Wisbech. East Anglian Archaeology 79.

Harrison, J.D. 1997. The Composite Manor of Brent: a study of a large wetland-edge estate up to 1350. Unpublished Ph.D. thesis, University of Leeds.

Hasted, E. 1797/1801. The history and topographical survey of the County of Kent. Reprinted 1972: Wakefield: E.P.Publishing.

Hatcher, J. 1970. Rural Economy and Society in the Duchy of Cornwall, 1300-1500. Cambridge: Cambridge University Press.

Hatcher, J. 1977. Plague, Population and the English Economy, 1348-1500. Cambridge: Cambridge University Press.

Hearne, C.M., Perkins, D.R.J. and Andrews, P. 1995. The Sandwich Bay Wastewater Treatment Scheme Archaeological Project, 1992-1994. Archaeologia Cantiana 115, 239-354. 
Hilton, R.H. 1947. The Economic Development of Some Leicestershire Estates in the 14th and 15th Centuries. London: Oxford University Press.

Hilton, R.H. 1957. Winchcombe Abbey and the Manor of Sherborne, pp. 89-113 in Finberg, H.P.R. (ed.) Gloucestershire Studies. Leicester: Leicester University Press.

Hipkin, S. 1995. The Impact of Marshland Drainage on Rye Harbour, 1550-1650. In Eddison, J. (ed.) 1995a, 138-48.

Holden, E.W. 1962. Desertted medieval villages. Sussex Notes and Queries 15(ix), 312-5.

Holloway, W. 1849. The History of Romney Marsh. London: John Russell Smith.

Homan, W.M. 1938. The Marshes Between Hythe and Pett. Sussex Archaeological Collections 88, 2241.

Hooke, D. 1985. Village development in the West Midlands, pp. 125-54 in Hooke, D. (ed.) Medieval Villages. Oxford: Oxford Committee for Archaeology monograph No. 5.

Hoskins, W.G. 1955. The Making of the English Landscape. London: Hodder and Stoughton.

Howell, C. 1983. Land, family and inheritance in transition: Kibworth Harcourt 1280-1700. Cambridge: Cambridge University Press.

Jensen, J., Hofstede, J.L.A., Kunz, H., Ronde, J. de, Heinen, P.F., and Siefert, W. 1993. Long term water level observations and variation, pp. 110-30 in Hillen, R. and Verhagen, H.J. (eds) Coastlines of the Southern North Sea. American Society of Engineers.

Keil, I.J.E. 1964. The Estates of Glastonbury Abbey in the Later Middle Ages. Unpublished Ph.D. thesis, University of Bristol.

Lamb, H.H. 1995. Climate History and the Modern World. 2nd edition. London: Routledge.

Linder, E 1946. The 'Red Hills' of Canvey Island - supplementary article. Essex Naturalist XXVII, $48-63$.

Lomas, T. 1984. South-east Durham: late fourteenth and fifteenth centuries, in Harvey, P.D.A. (ed.) The Peasant Land Market in Medieval England. Oxford.

Lovegrove, H. 1994. Official Guide to the ancient town of Winchelsea. Winchelsea Coporation.

Mate, M. 1991. The agrarian economy of south-east England before the Black Death: degressed or bouyant?, pp. 78-109 in Campbell, B.M.S. (ed) Before the Black Death: studies in the 'crisis' of the early fourteenth century. Manchester: Manchester University Press.

Mate, M. 1997. Agricultural technology in Southeast England, 1348-1530, pp. 251-74 in Astill, G. and Langdon, J. (eds). Medieval Farming and Technology. Leiden: Brill.

McLane, B.W. 1988. The 1341 Royal Inquest in Lincolnshire. Lincolnshire Records Society 78.

Miller, E. 1951. The Abbey and Bishopric of Ely. Cambridge: Cambridge University Press.

Miller, E. (ed.) 1991a. The Agrarian History of England and Wales, volume 111, 1348-1500. Cambridge: Cambridge University Press.

Miller,E. 1991b. Introduction: land and people. In Miller, E. (ed.) 1991a, 1-33.

Moffat, B. 1986. The environment of Battle Abbey Estates (East Sussex) in medieval times: a reevaluation using analysis of pollen and sediments. Landscape History 8, 77-93.

Morant, P. 1763/8. The History and Antiquities of the County of Essex. Reprinted 1978. Chelmsford: Essex County Libraries.

Murphy, P. 1993 Anglo-Saxon arable farming on the silt-fens: preliminary results. Fenland Research 8, 75-8.

Murphy, P. 1995 Environmental Archaeology: Third Progress Report. Fenland Research 9, $26-9$.

Musgrove, D.J. 1999. The Medieval Exploitation of the Peat Moors of the Somerset Levels. Unpublished Ph.D., University of Exeter.

Newton, K.C. 1970. The manor of Writtle: the development of a royal manor in Essex, c.1086-c.1500. Chichester: Phillimore.

Nichols, J.F. 1925. New Light on the History of Milton Hamlet. Transactions of the Southend-on-Sea Antiquarian and Historical Society I, 172-81.

Nichols, J.F. 1932. Milton Hall: the compotus of 1299. Transactions of the Southend-on-Sea Antiquarian and Historical Society II, 113-67.

Norden, J. 1594. Sepculi britanniae pars: an historical and chorographical description of the County of Essex. Reprinted 1840. London: Camden Society. 
Overton, M. and Campbell, B.M.S. 1999. Statistics of production and productivity in English agriculture 1086-1871, in van Bavel, B.J.P. and Thoen, E. (eds) Land Productivity and AgroSystems in the North Sea Area (Middle Ages - 20th Century. Brepols pp 189-208.

Owen, A.E.B. 1996. The Medieval Lindsey Marsh: Select Documents. Lincolnshire Records Society 85.

Page, W. 1937. The Borough of Rye. Victoria County History of Kent 9, 39-62.

Pearson, S. 1994. The Medieval; Houses of Kent: an historical analysis. Swindon: RCHME.

Pearson, S. 1995. The Medieval Houses of the Marsh: the missing evidence. In Eddison, J. (ed.) 1995a, 92-98.

Poos, L.R. 1985. The rural population of Essex in the later middle ages, Economic History Review, 2nd ser., XXXVIII,

Postan, M.M. 1966. The Cambridge EconomicHistory of Europe. Volume 1: The Agrarian Life of the Middle Ages. 2nd Ed. Cambridge: Cambridge University Press.

Postan, M.M. 1972. The Medieval Economy and Society. London: Weidenfield and Nicholson.

Postan, M.M. 1973. Essays on Medieval Agriculture and General Problems of the Medieval Economy, Cambridge: Cambridge University Press.

Priestley, H.E. 1984. A History of Benfleet. Benfleet: Castle Point District Council.

Razi, Z. 1980. Life, Marriage and Death in a Medieval Parish: Economy, Society and Demography in Halesowen, 1270-1400. Cambridge.

Reaney, P.H. 1935: The Place-Names of Essex. English Place-Names Society XII.

Reeves, A. 1995. Romney Marsh: the fieldwalking evidence. In Eddison, J. (ed.) 1995, 78-92.

Rigby, S.H. 1993. Medieval Grimsby: Growth and Decline. Hull: University of Hull Press.

Riley, H.T. 1874. Manuscripts of the Corporation of New Romney. Historic Manuscripts Commission, 4 th report, pt. 1, 439-42.

Riley, H.T. 1876a. The Corporation of Lydd, Kent. Historic Manuscripts Commission, 5th report, pt. 1, 516-33.

Riley, H.T. 1876b. Manuscripts of the Corporation of New Romney Second Notice. Historic Manuscripts Commission, 5th report, pt. 1, 533-54.

Rippon, S. 1996. The Gwent Levels: the evolution of a wetland landscape. York: CBA Res Rep 105.

Rippon, S. 1997a. The Severn Estuary: landscape evolution and wetland reclamation. London: Leicester University Press

Rippon, S. 1997b. Roman and Medieval Settlement on the North Somerset Levels: the second season of survey and excavation at Banwell and Puxton, 1997. Archaeology in the Severn Estuary $8,41-54$.

Rippon, S. 2000a. The Transformation of Marshland Landscapes. London: The British Academy.

Rippon, S. forthcoming. Fields of beans and flocks of sheep: the perception of wetland landscapes during the medieval period. In Bell, M. and Boardman, (eds) Geoarchaeology: Landscape Change Over Archaeological Timescales.

Roberts, B.K. and Wrathmell, S. 2000. People of wood and plain: an exploration of national and local regional contrasts, pp. 84-95 in Hooke, D. (ed.) Landscape: the richest historical record. Society for Landscape Studies supplementary series 1.

Robertson, W.A.S. 1880. Destroyed Churches of New Romney. Archaeologia Cantiana 13, 237-49.

Round, J.H. 1906. The Domesday Survey, Victoria County History of Somerset 1, 333-598.

Sabin, A. 1960. Some manorial Accounts of St Augustine's Abbey, Bristol being the Computa of the Manors for 1491-2 and 1496-7. Bristol Records Society XXII.

Salzman, L.F. 1937. Broomhill. Victoria County History of Kent 9, 148-52.

Sheail, J. 1968. The Regional Distribution of Wealth in England and Indicated by the 1524/5 Lay Subsidy Rolls. Unpublished Thesis, University of London.

Searle, E. 1974. Lordship and Community. Battle Abbey and its banlieu 1066-1538. Toronto: Pontifical Inst. of Medieval Studies.

Searle, E. and Ross, B. 1967. Accounts of the Cellarers of Battle Abbey 1275-1513. Sydney: Sydney University Press.

Sheppard, J.A. 1966. The Draining of the Marshlands of South Holderness and the Vale of York. York: East Yorkshire Local History Society. 
Silvester, R.J. 1988. The Fenland Project, Number 3: Norfolk Survey, Marshland and Nar Valley. East Anglian Archaeology 45.

Smith, J.R. 1970. Foulness: A history of an Essex island parish. Chelmsford: Essex Records Office.

Smith, R.A.L. 1940. Marsh embankment and sea defence in medieval Kent. Economic History Review 10(i), 29-37.

Smith, R.A.L. 1943. Canterbury Cathedral Priory: a study in monastic administration. Cambridge: Cambridge University Press.

Spurrell, F.C.J. 1885. Early sites and embankments on the margins of the Thames Estuary. Archaeol. J. 42, 269-302.

Start, D. 1993. Deserted Medieval Villages, pp. 52-3 in Bennett, S. and Bennett, N. (eds.) An Historical Atlas of Lincolnshire. Hull: University of Hull Press.

Stone, D. 1998. Management of Resources on the Demesne Farm of Wisbech Barton, 1314-1430. Unpublished Ph.D. thesis, University of Cambridge.

Tatton-Brown, T. 1988. The topography of the Walland Marsh area between the eleventh and thirteenth centuries, in Eddison, J. and Green, C. (eds.), 105-11.

Tatton-Brown, T. 1989. Church Building on Romney Marsh in the Later Middle Ages. Archaeologia Cantiana CVII, 253-65.

Thirsk, J. 1967. Enclosing and Engrossing, pp. 200-55 in Thirsk, J. (ed.) The Agrarian History of England and Wales IV: 1500-1640. Cambridge, Cambridge University Press.

Thomson, W.S. 1944. A Lincolnshire Assize Roll for 1298. Lincolnshire Records Society 36.

Thornton, C. 1991. The determinants of land productivity on the Bishop of Winchester's demesne at Rimpton, 1208 to 1403, pp. 183-210 in Campbell, B.M.S. and Overton, M. (eds) Land, Labour and Livestock. Manchester: Manchester University Press.

Titow, J.Z. 1961 Some evidence of thirteenth-century population increase, Economic History Review, 2nd ser., XIV,

Titow, J.Z. 1969. English Rural Society 1200-1350. London: George Allen and Unwin.

Titow, J.Z. 1972. Winchester Yields: a study in medieval agricultural productivity. Cambridge: Cambridge University Press.

Toulmin Smith, L. 1907. The Itinerary of John Leland in or about the years 1535-1543. London: George Bell and Sons.

Tusser, T. 1557. Five Hundred Points of Good Husbandry .... Reprinted 1812, ed. William Mavor, London.

Vollans, E. 1988. New Romney and the 'river Newenden' in the later Middle Ages, in Eddison, J. and Green, C. (eds), 128-41.

Waites, B. 1966. A Yorkshire Farmer in the memoranda Rolls. Yorkshire Archaeological Journal XLI, $445-8$

Ward, G. 1920. The evolution of the Hastings coastline. Geographical Journal 56, 107-123.

Williamson, T. 1997. The Norfolk Broads: A Landscape History. Manchester: Manchester University Press.

Wretts-Smith, M. 1931/32. Organisation of Farming at Croyland Abbey 1257-1321. Journal of Economic and Business History IV, 168-92.

Young, R. and Simmonds, T. 1995. Marginality and the nature of later prehistoric upland settlement in the north of England. Landscape History 17, 5-15. 